\title{
建築市場・ニーズの変化とこれからの建築系教育 \\ FUTURE ARCHITECTURAL EDUCATION IN CONNECTION WITH CHANGE OF ARCHITECTURAL MARKET AND NEEDS
}

\author{
榊 原潤* \\ Jun SAKAKIHARA
}

\begin{abstract}
Architectural needs has changed, diversified and become complicated due to the change of society, economy and architectural market in Japan According to these trends, relevant architectural scope and related parties are spread from the basic architectural work (plan, design and construction) through whole process and in each phase. Various professionals participate to correspond to architectural needs and 'management' of their works becomes more important.

This paper proposes to strengthen the education of 'management' in architectural education, throughout the investigation of architectural needs and practical work in architectural industry, and the goal of study based on 'JABEE' standard of architectural education.
\end{abstract}

Keywords: Architectural Education, Change of market and needs, Spread of business domain, JABEE, Management 建築系教育、建築市場とニーズの変化、業務領域の桩大、JABEE、マネジメント

\section{1. 研究の背貴と目的}

高度経済成長に伴う建築市場の拡大、バブルの勃興と崩壊、その後 の建築市場の縮减を経て市場の建築ニーズは変化し、多様化、複雑化 しており、実業の業務にも大きな変化が見られる。建築づくりの基幹 業務 (計画・設計・施工) の上流 (事業企画)、下流（運営・維持管 理）一の業務領域の拡大、基幹業務各段階の関連業務の增加に伴い、 複数の専門家の協働なしには実現し得ない案件が增加し、多様化した 業務の「マネジメント」が重要性を增している。一方建築系教育では JABEE 認定基準がマネジメント側面を内包しているものの、基淮と しては明確に位置づけられておらず、建築におけるマネジメント教育 に関する研究も少ない。1)

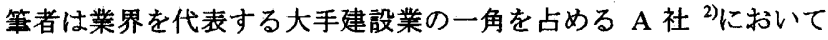
過去 6 年間設計・プロポーザル機能の企画運営に携わり、依頼業務の 申込受付、依頼内容のヒアリングや案件情報の展開を担当してきた。

こうした実業での実務に関するデータとJABEE 建築分野教育認定 審査への参画等により得られた建築系教育に関するデータに基づき、 現状の建築系教育におけるマネジメント教育の不足と、今後の建築系 教育でのマネジメント教育の必要性、重要性について考察する。

\section{2. 市場の変化}

\section{$2-1$ 建筑投資の推移}

戦後の高度経済成長のもと、総じて右有上がりの成長を続けてきた 建築投資は、1980 年代の半ばから 1990 年にかけて、民間投資を中心 に急拡大を遂げ 1990 年度には 52.2 兆円に達した。バブル経済崩壊後 は潮减し 2003 年度には $45 \%$ 減の 28.7 兆円にまで落ち込んだが、民間 建築投資の増加により 2004 年度には 29.3 兆円に回復した。
$\mathrm{A}$ 社建築受注額も 2003 年度に 7 年ぶりに増加に転じたが、バブル 末期と比心゙半堿（2004 年/1991 年 : $50 \%$ 減）した。受注が减少する 中で設計業務依頼件数は増加（2003 年/1998 年：45\%增）し、営業 設計、設計見糟合せ等発注が未定の案件（設計施工特命以外の案件） 比率が大幅に增加（1990年：53.5\% $\rightarrow 2004$ 年 : $78.1 \%$ 、件数比 2 倍） した。(図1)これは市場縮减の中での受注確保の競争激化を示すと共 に、建築市場・ニーズの多様化を反映したものと考えられる。

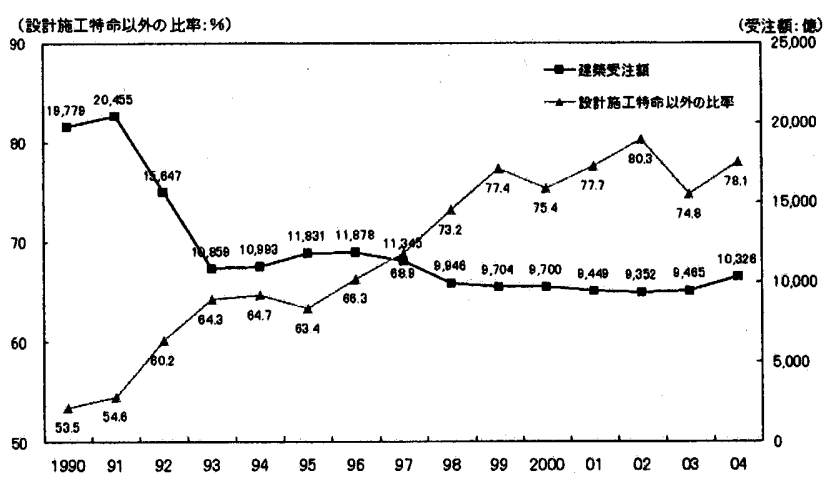

図1 A 社建築工事受注額及び黨業設計等の依頼件数比率の推移

\section{$2-2$ 建築ニーズの変化}

設計・プロポーザル業務は案件申込書による業務依頼に基づいて行 われ申込件数は設計、プロポーザル業務とも増加している。（設計／ 1996 年: 2,502 件、2005 年: 3,377 件、件数比 $35 \%$ 増、プロポーザル [2002 発足] / 2003 年 : 707 件、2005 年: 846 件、件数比 $20 \%$ 增) 以 下、申込書記載の建築ニーズの変化をいくつかの側面から考察する。
* 元 清水建設(侏)設計・プロポーザル統括

現 武庫川女子大学生活環境学部建築学科
General Manager, Planning, Design \& Consulting Division Shimizu Corporation Prof., Department of Architecture, Mukogawa Women's University 
（1）施設用途別ニーズの多様化、複雑化

用途別の依頼件数比率（1996 年～2005 年）は生産施設 $(20.1 \% \rightarrow$ $26.7 \%)$ 、医療施設 $(4.7 \% \rightarrow 6.9 \%)$ 、集合住宅 $(16.6 \% \rightarrow 11.1 \%)$ の変 動が大きくその他の用途には大きな変動は無いが、各用途とも最近の 依頼内容には下記のような多様化、複雑化がみられる。

-生産施設 : 半導体、液晶、医楽品等高性能の生産・研究環境が求め られる案件、プラント等周辺設備を含む計画案件

・物流施設 : 外資系の参入による貸貸大型多層物流センター案件、加 エライン・物流システムを組み込んだ案件

- 事 務 所 : 都市開発手法の活用が必要な、再開発・跡地開発型の大 型案件、不動産流動化を反映した投資対象案件

・物販施設 : 商業コンサルタントとの連揍による大型複合商業施設、 個性化小店舗、高級ブランド旗艦店舗等案件の多様化

・集合住宅:都心居住型の開発手法の活用やローコスト対応が求めら れる超高層大型集合住宅案件

- 医療施設 : 補助金削减の中、事業コンサルティングに基づく事業企 画を含む高齢化に向けた施設整備案件

- 教育施設 : 少子化の中、学生・生徒の確保に向けた全体整備案件や 学生・生徒数予測に基づくキャンパス整備案件

（2）リニューアルニーズの增加、多様化

リニューアル工事への投資比率の增大（1990 代半ば：13〜15\% $\rightarrow$ $2003: 23.0 \%)^{1)}$ に伴い、設計・プロポーザル業務の依頼件数（工事 種別）も增改筑が增加（1998 年：29.7\% $\rightarrow 2004$ 年：49.9\%、件数比 2.4 倍）している。従来からの増改築・改修に加え、施設及び利用状 況の診断・コンサルティング、デューデリジェンスによる格付向上や コンバージョンによる再活性化等、以下のような多様化が見られる。

・改 装: 事業計画（集客力向上、テナント誘致等）に基づく施設 の内外装、インテリア、外構等の改装、イメージアップ

- 機能向上 : 事業・機能診断に基づく生産・維持管理機能向上のため の、生産機器更新、情報・運営システム導入・更新

・性能向上 : 建物性能診断に基づく耐震改修（免震化、耐震補強）に よる長寿命化、居住性、快適性、環境性能等の向上

・省エネ化 : 生涯維持管理費削堿コンサルティングに基づく、設備の 更新（システム、熱源、機器等）、リース化等

・機能変更 : 施設全体整備コンサルティングに基づく、使い勝手・レ イアウトの変更、運営・管理方式の変更

・用途変更 : 施設事業コンサルティングに基づくニーズ、事業性の高 い用途への変更による有効活用（コンバージョン）

\section{（3）業務依頼形態の多様化}

建築ニーズの変化・多様化に伴い、設計・プロポーザル業務の依頼 形態も以下のように多様化している。

・コンサルティング案件（プロポーザル機能が担当）の増加：発注 者の施設建設、運営効率化等に関する事業意思決定のためのコン サルティング（2-2 参照）

・設計施工特命案件比率の減少（1996 年：33.7\%、2005 年 : $21.9 \%$ ） による特命以外の案件比率の増加。うち営業設計と設計見積合せ の合計は减少 (1996 年 : $56.4 \% 、 2005$ 年 : $44.3 \%$ )。

・代って設計事務所の設計への技術協力や、企画・基本設計十実施
設計・施工方式（設計事務所：企画・基本設計、建設会社 : 実施 設計・施工）など設計事務所と連携した設計依賴案件が大幅增加 (件数比率 1996 年 : $4.9 \% 、 2005$ 年 : $34.2 \%$ 、件数比 9.4 倍)

・事業企画から運営までの一式を提案するコンソーシアムの一員と して設計・プロポーザル機能が参画する PFI 案件の增加（2003〜 2,005 年合計 36 件)

3. 建築ニーズの変化、多様化と関与者の増加、多様化

$\mathrm{A}$ 社では主要案件について取組方針検討会議を開催し、ニーズの深 堀り、取組方針具体化、課題解決のシナリオ構築、関与者選定、スケ ジュール設定等を行っている。ニーズへの対応を「事業企画」「計画・ 設計・施工」、「運営・維持管理」の3つの段階に分け、の依頼内容か ら読み取れる各段階の特徴的なニーズ・課題と、ニーズ具体化、課題 解決の関与者を下記の分類により整理すると以下のようになる。

(1) 関与者の分類

$\mathrm{A} /$ 関倸者 : 建築の所有者、利用者、管理者、地域住民、行政等

B／計画・設計系専門家 : 建築の計画・設計に搭わる建築系専門家

$\mathrm{C} /$ 生産・施工系専門家 : 建築の生産・施工に搭わる建築系専門家

D /その他建築系専門家 : 積算、品質管理、維持保全等 B、C 以外 の建築関連業務に携わる建築系専門家

$\mathrm{E} /$ 建築以外の専門家：事業企画、運営・維持管理や、建築以外の エンジニアリング等の関連業務に萼わる専門家

(2) 凡例

$\underline{\mathrm{x}}$ (下線) /関与者、可（曲み）/とりまとめを行う関与者 (ケース、段階により関与者、とりまとめを行う関与者が異なる場 合はそのす心゙てを表示)

\section{3-1 事莱企画段階}

1. 発注者の立場に立った事業、技術及び施設のコンサルティング、 及び発注者の立場での事業ニーズの具体化 $(\underline{\mathrm{A}} \cdot \mathrm{B} \cdot \mathrm{C} \cdot \mathrm{B} \cdot$ 国 $)$

2. 地域に密着し、住民・事業者と一体となった施設ニーズの具体化 $(\underline{A} \cdot \mathbf{B} \cdot \mathbf{C} \cdot \mathbf{D} \cdot \mathbf{E})$

3. 工場、商業施設、社宅等の閉鎖堌加に伴う、跡地有效利用企画 (事 業・施設企画等)

$(\underline{A} \cdot \mathbf{B} \cdot \mathbf{C} \cdot \mathbf{D} \cdot$ 国 $)$

4. 市街地再開発、都市再生特区等の手法を活用した、地域開発企画 に基づく施設事業化ニーズの誘尊 （

5. 建築費の融資、補助金等の申請のための事業計画・施設企画

$(\underline{\mathrm{A}} \cdot \mathrm{B} \cdot \mathrm{C} \cdot \mathrm{D} \cdot \mathrm{E})$

6. 建築の動産化（不動産投資信託等）に対応した、事業及び施設企 画 $(\underline{A} \cdot \mathrm{B} \cdot \mathrm{C} \cdot \mathrm{D} \cdot \mathrm{E})$

3-2 㖕画・設計・施工段階

1. 施設ニーズの多様化、複雑化、社会ニーズの高度化に伴う設計条 件の的確な構第

$(\underline{A} \cdot \mathrm{B} \cdot \mathrm{C} \cdot \mathrm{D} \cdot \underline{\mathrm{E}})$

2. 性能目標值を明確にした施設づくり（仕様から性能へ、性能設 計・施工) $(\underline{\mathrm{A}} \cdot \mathrm{B} \cdot \mathrm{\textrm {C }} \cdot \underline{\mathrm{D}} \cdot \underline{\mathrm{E}})$

3. 設計・施工・検查を一貫した高度な品質・性能確保・保証が必要 となる施設づくり（液晶・半導体工場等）（A・且・因・ $\underline{\mathrm{D}} \cdot \mathrm{E} ）$

4. 建築、プラント、装置等を一体化した施設づくり（高機能の生産、 研究、医療、情報通信施設等)

$(\underline{A} \cdot \mathrm{B} \cdot \mathrm{A} \cdot \underline{\mathrm{D}} \cdot \mathrm{E})$ 
5. 環境負荷低减に取組んだ施設づくり(省エネルギー、L C C 削減、 ヒートアイランド防止、省資源、省廃㲤物等） $(\underline{A} \cdot \mathbf{B} \cdot \underline{\mathrm{g}} \cdot \underline{\mathrm{D}} \cdot \underline{\mathrm{E}})$

6. リスクマネジメントの一玮として、BCP (事業継続計画) の観点 から地震防災等を織り込んだ施設づくり $(\underline{\mathrm{A}} \cdot \mathrm{B} \cdot \mathrm{G} \cdot \underline{\mathrm{D}} \cdot \mathrm{E})$

7. 専門家の参画增加に伴う、トータルなデザインのコーディネート

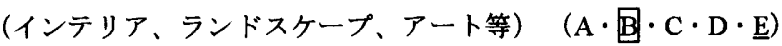

8. リニューアルの増加に伴う、設計、施工、情報化対応、家具・備 品の計画・調達などのパッケージ对応 $\quad(\mathrm{A} \cdot \underline{\mathrm{B}} \cdot \mathrm{g} \cdot \mathrm{D} \cdot \underline{\mathrm{E}})$

9. 建築生産改革 (IT 活用、3D-CAD シミュレーション、設計・施工 データ連動、工業化、短工期化技術開発等）（A・

10. 幅広いニーズへの総合力による対応 (プロポーザル方式、技術提

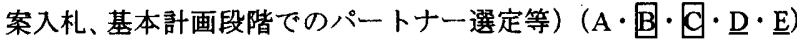

\section{3-3 運黨、維持管理段陵}

1. 耐震診断、耐震補強・免震化等による地震時の安全性の向上

$(\mathrm{A} \cdot \mathrm{B} \cdot \mathrm{g} \cdot \mathrm{D} \cdot \mathrm{E})$

2. 設備機器更新、設備システム変更によるライフサイクルコストの
削减

$(\underline{\mathrm{A}} \cdot \mathrm{B} \cdot \mathrm{G} \cdot \mathrm{D} \cdot \underline{\mathrm{E}})$

3. 施設運用段階の票境負荷低减（LCCO2、LCW 等の削減のための データ収集と運用への反映)

$($ 目. B $\cdot \mathrm{C} \cdot \mathrm{D} \cdot$ 国 $)$

4. 建物性能の保証、保全（設備機器のコミッショニング、躯体安全 性、室内空気環境等のモニタリング)

$(\mathrm{A} \cdot \underline{\mathrm{B}} \cdot \underline{\mathrm{C}} \cdot \mathrm{D} \cdot \mathrm{E})$

5. 施設長期利用化一の体系的対応 (建物長寿命化、改装、機能更新

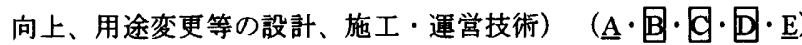

6. 増改築、建替、売却等施設及び敷地活用方法検討への対応 (耐震、

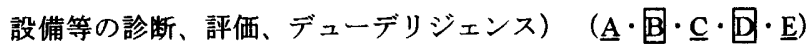

3ー4 ライフサイクル（事業企画～運営・維持管理段階）全体

1. 事業企画から運営・稚持管理までの全段階を通した事業プロデュ ース、プロジェクトマネジメント (PM、PFI) $(\underline{\mathrm{A}} \cdot \mathrm{B} \cdot \mathrm{g} \cdot \underline{\mathrm{D}} \cdot \mathrm{E})$

2. 事業企画から維持管理、増改築、建替に至るまでの、コンサルテ

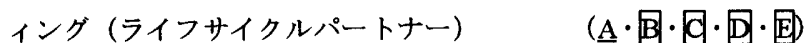

3. 建築を事業投資や資産の対象として捉えたマネジメント（FM、 アセット/プロパティ・マネジメント)

$(\underline{\mathrm{A}} \cdot \underline{\mathrm{B}} \cdot \mathrm{C} \cdot \mathrm{D} \cdot \mathrm{E})$

表1 建築のライフサイクルにわたる関与専門家別の業務内容

（下線表記 : 統括、取りまとめ、総合化が必要な業務)

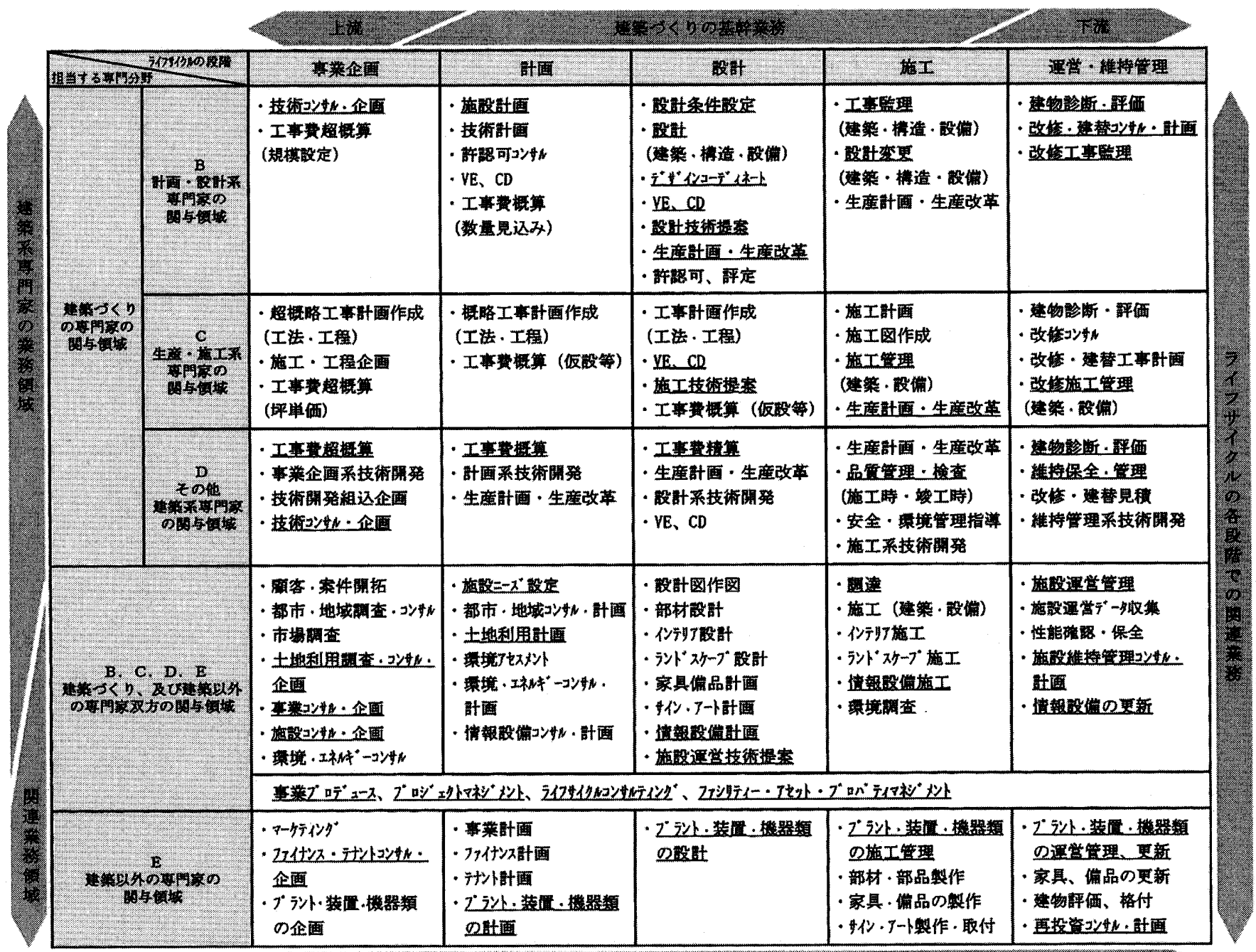




\section{4. 建築系業務の拡大、多様化とマネジメント}

\section{4-1 建築ニーズへの対応莱務の桩大、多様化}

建築のライフサイクルの段階 (事業企画、計画・設計・施工、運営 · 維持管理）と主な関与専門家（前章の「関与者の分類」参照）とによ り、従来からの建築づくりのニーズへの対応業務と、前章で分析した 最近のニーズへの対応業務（前章の対応を業務に置き換えたもの）及 び複数の関倸者や尃門家が関与する業務の統括、取りまとめや総合化 の業務（下線表記）を分類すると表 1 のようになる。

このように建築ニーズへの対応業務が应大、多様化しており、その 取りまとめや総合化の業務が必要なものが多いことが分かる。

\section{4-2 業務の拡大、多様化とマネジメント}

A 社の設計・プロポーザル業務の依頼内容及び対応業務実態の調 査・分析の結果を概念的に図示すると図 2 のようになる。即ち計画・ 設計・施工という建築づくりの基幹業務の上流（事業企画段階）・下 流（運営・維持管理段階）人と建築ニーズが拡大・多様化し、一方計 画・設計・施工においてもニーズが多様化・高度化（デザイン、エン ジニアリング等) してきた。これに伴いニーズへの対応業務も領域が 桩大し、多栏化・高度化・複雑化しており、関与する関倸者や專門家 の種別や人数も增加している。このように多様化・高度化・複雑化し、 複数の関保者や専門家が関与する業務の「統括」「取りまとめ」や「総 合化」のための、マネジメント機能が必要不可欠になってきている。 またライフサイクル全体を通したマネジメント(プロジェクトマネジ メント、ファシリティーマネジメント等）も、建築ニーズへの対応業 務として重要になってきている。

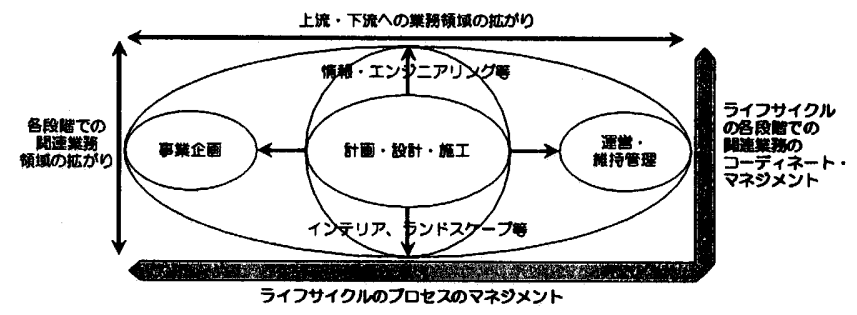

图2 建築づくりの莱務領域の拡大·多様化とマネジメント

\section{5. 建築系教育とマネジメント}

\section{5-1 建築系教育のマネジメントヘの対応}

以上建築ニーズの桩大・多様化への対応のため、建築系業務におけ るマネジメントの重要性が増大しているという実業の実態の調查・分 析を行ってきた。引き続きこうした害業の動向に対する建築系教育の 対応について、調查、分析し考察を行う。

まず建築系教育においてマネジメントがどのように位㯰付けられ 実践されているかについて、客観的に認知度が高く体系的に整理され た、「JABEE」学習・教育目標の設定基準、「建築学および建築学関連 分野」の分野別要件と既認定校の学習・教育目標を調查・分析する。

\section{5-2「JABEEJ基準におけるマネジメント侧面の位置付け}

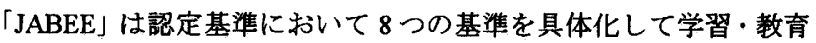
目標として設定するよう求めている ${ }^{4)}$ が、8つの基準をマネジメント の視点から分析してみると、いずれも以下のようにマネジメントとの 関連が深い側面を内包している。 （a）多面的思考能力：地球的視点からの多面的な物事の考察

（b）技術者倫理：技術が社会および自然に及ぼす影響・効果、技術 者が社会に対して負っている責任に関する理解

（c）工学基䔎能力：数学、自然科学および情報技術に関する知識と それらの応用

（d）専門技術力：専門技術に関する知識とその問題解決への応用

（e）デザイン能力：種々の科学、技術および情報を利用して社会の 要求を解決するためのデザイン

（f）コミュニケーション：日本語による論理的な記述、口頭発表、 討議等のコミュニケーションおよび国際的に通用するコミュニ ケーション

(g) 継続的学習 : 自主的、継続的な学習

（h）仕事の遂行、まとめ：与えられた制約の下での計画的な仕事の 推進とまとめ

一方建築学および建築学関連分野の分野別要件 ${ }^{3)}$ にも、習得すべ き知識・能力の 2 項目共にマネジメントに関する側面が含まれている。

(1) 建築学分野の包括的な専門知識・能力

- 紜合的かつ体系的な識見に基づく、企画・設計・生産・維持管理 などの実施

(2) 建築にかかわる特定領域の高度な専門的知識・能力

・包括的知識をより発展させた知識の実用への適用

そしてそれぞれ「建築設計・計画」「建築環境・設備」「建築構造」、

「建築生産」の 4 分類（包括的・基硶的な専門知識・能力では「左記 4 分類以外」を加えた 5 分類）において知識・能力等の内容を定めて いる3) が、以下のようなマネジメントに関する側面を含んでいる。

(1) 包括的・基碗的な専門知識・能力

- 建築設計・計画

・成果物及びロ頭でのコミュニケーションを中心とした表現

- 建築生産

・企画・設計から施工・維持管理・保全にいたるまでのプロセス と技術、業務の基礶知識

・建築のライフサイクルを通じた基硠知識と、企画・設計・生産 との関係の理解

(2) 特定領域の高度な専門知識・能力

・建築設計・計画

・建築設計・計画に関する実践

- 建筑環境・設備

・尃門的な知識・能力を総合化した応用

- 建築構造

・知識の統合 (体系)化を通じた実践

・技術者倫理に関する知識

\section{5-3 学習・教育目標におけるマネジメント側面の展開}

次に「JABEE」の 8 つの基準に内包されたマネジメントの考え方が、 既に認定を取得した 8 つの建築系プログラム $(\mathrm{A} \sim \mathrm{H})$ の 13)のホーム ページに記載された学習·教育目標にどのように展開されているかを 調查し、建築づくりのマネジメントに求められる基本姿勢、知識、能 力に関する記述を基準ごとに整理し一覧にすると表 2 のうになり、 各プログラムとも様々な切り口からマネジメントにかかわりの深い 側面を学習・教育目標に組み入れていることが分かる。 


\begin{tabular}{|c|c|c|c|c|c|c|c|c|}
\hline & 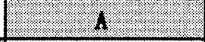 & B & C & D & $\mathrm{E}$ & F & G & $\mathrm{H}$ \\
\hline (a) & 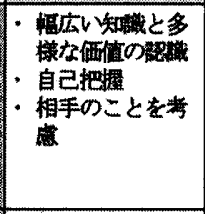 & 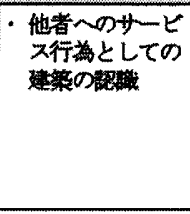 & 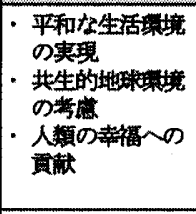 & & 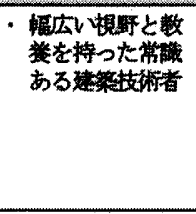 & 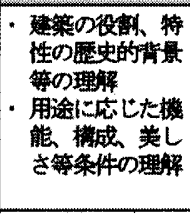 & 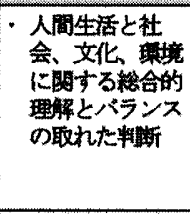 & 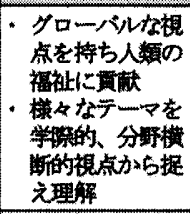 \\
\hline (6) & 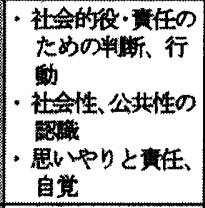 & 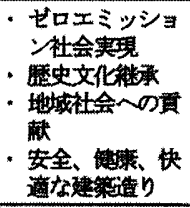 & 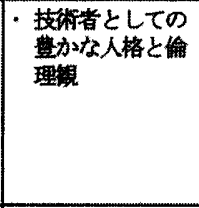 & 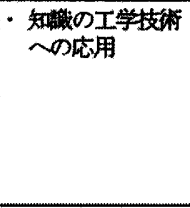 & 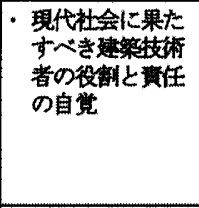 & 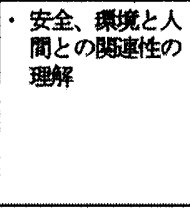 & 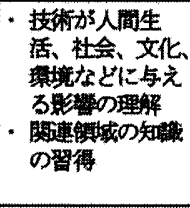 & 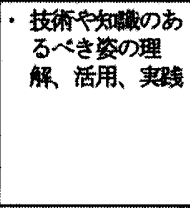 \\
\hline$\frac{6}{4}$ & 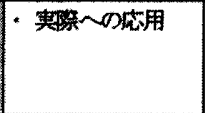 & & - 建筑への底用 & - 物理的事象の理 & 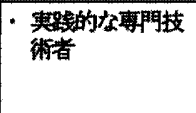 & & 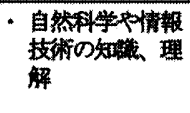 & - 情教の銓理的分 \\
\hline & 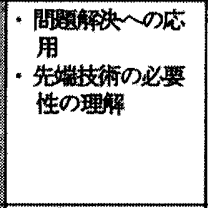 & 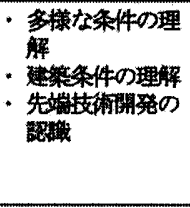 & 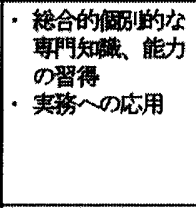 & 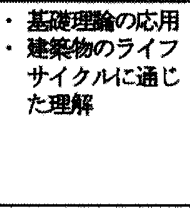 & 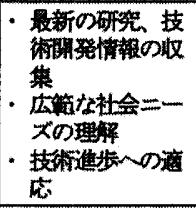 & 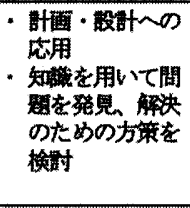 & 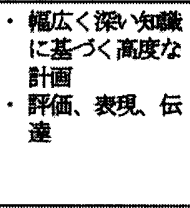 & 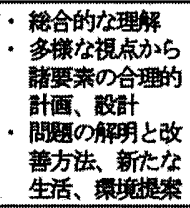 \\
\hline$\frac{(a)}{3}+x^{2} \operatorname{sen}$ & 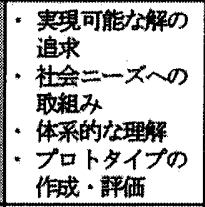 & & 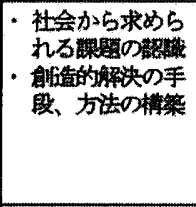 & & 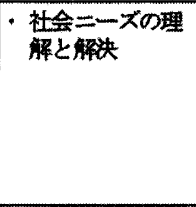 & 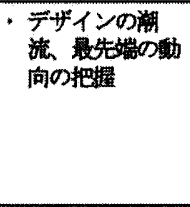 & 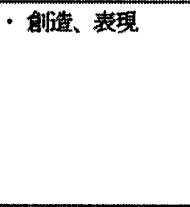 & 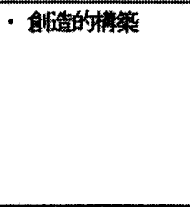 \\
\hline $\begin{array}{l}60 \\
32=-3-2\end{array}$ & 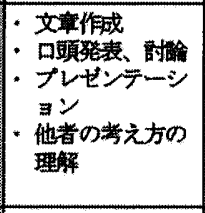 & 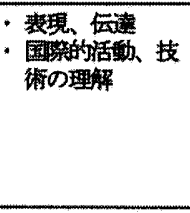 & 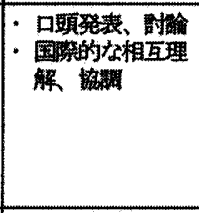 & $\begin{array}{l}\text { 国绦的な子技術交 } \\
\text { 流、活動 }\end{array}$ & 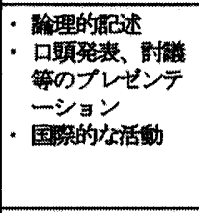 & 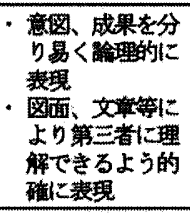 & 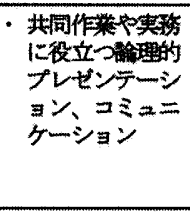 & 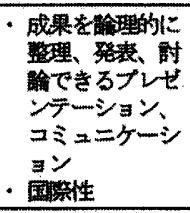 \\
\hline (c) & 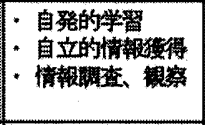 & & 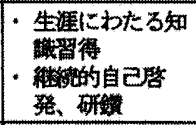 & & 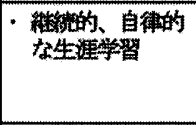 & $\begin{array}{l}\text { 自50笔留計画 } \\
\text { O立宋 }\end{array}$ & 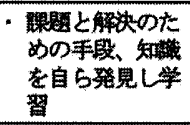 & 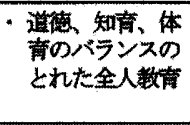 \\
\hline 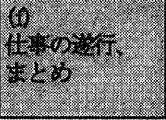 & 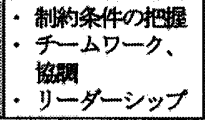 & 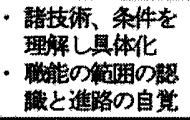 & 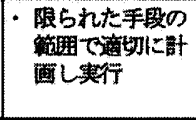 & 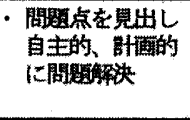 & $\begin{array}{l}\text { 主体的、計醐的 } \\
\text { な仕事の推進 }\end{array}$ & 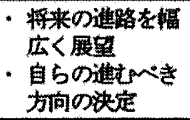 & 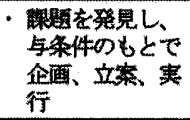 & 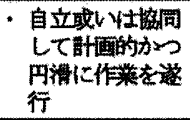 \\
\hline
\end{tabular}

\section{5-4 マネジメントの知識・能力}

実業の実務におけるマネジメントの害際及び「JABEE」認定プロ グラムの学習・教育目標へのマネジメント側面の組み入れの調查・ 分析に基づき、建築系教育に求められるマネジメントに関する知 識・能力をまとめると、概ね以下のような内容になると考えられる。

（技術者倫理とコミュニケーションは共に個々の認知度、独立性が 高く、マネジメントと共に「共通に必要な知識・能力」を構成する 知識・能力として別に扱う。)

（1）マネジメントに関する基本姿勢・条件

・グローバルな視点と多様な価値観の認識

-人文科学・自然科学分野、語学及び専門分野の幅広い知識・理解

・技術者倫理の考え方の正しい理解・認識

・コミュニケーションのあり方の正しい認識と実践

・自主性、協調性、継続性、リーダーシップ

（2）マネジメントに関する知識

・建築に関わる社会、消費者の基本ニーズ : 良質、安全、安価、 省エネルギー、環境への配慮等
・建築のライフサイクルの全体像及びプロセス : 事業企画、計画・ 設計・施工、運営・維持管理、更新

・デザインマネジメント：トータルコンセプトの明確化、建築、

外構、インテリア、家具、アート等デザインの総合化

・技術マネジメント：ニーズの把握、技術開発、継続的改良

・生産マネジメント：建築・設備総合化、工程、コスト、安全等

- 建築に関わる規制・推進策 : 法規制、行政施策、融資、補助金等

・建築に関わる諸手続き：発注、契約、許認可、検査、点検等

- 施設の維持管理 : 敷地、建築、設備、家具・備品等の管理、運営

- 建築の関保者 : 発注者、所有者、利用者、管理者、住民、行政等

・建筑づくりの専門家 : 事業企画、計画・設計・施工、維持保全等 の関連組織及び各領域の専門家

・建築に関わる資格：建築士、建築設㣁士、施工管理技士等

・建築に関わるマネジメントの専門家：PM、CM、BM、FM 等

（3）マネジメントに関する能力

・構想力：課題発見、創造的発想、実現可能な解の追及

-計画力：条件把提、条件具体化、達成目標の理解、技術力活用 
- 判断·意思決定力: 多面的な思考、調查分析、比較検討、決断 - 合意形成力 : ニーズの把握、考え方の整理、意思決定の誘導

・実行力 : 知識・認識の建築等実際への応用、計画の実施

・設計マネジメントカ：コンセプト、建築、構造、設備の総合化

・組織マネジメントカ：共同作業の連㔗推進、統率

\section{5-5 共通知識・能力としてのマネジメントの位置付け}

以上の調查・分析により、「JABEE」認定プログラムの学習・教育 目標にはマネジメントに関する側面が数多く含まれているが分散し ておりマネジメントとして体系的には記述されていないこと、またカ リキュラムの調查により、マネジメントを教育科目としているのはプ

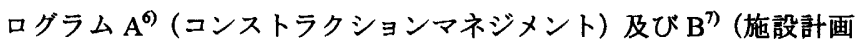
マネジメント総論及び演習) だけであることが分かった。

そこでマネジメント教育の徽底を図るためマネジメント等専門性 を超えて共通に必要とされる知識・能力を学習・教育目標の分野別要 件に位置付ける事を提案する。建築学および建築学関連分野において、 習得すべき知識・能力として規定された「建築学分野の包括的な専門 知識・能力小、建築にかかわる特定領域の高度な専門知識・能力」に 加え、マネジメントを「建築にかかわる共通知識・能力」として位置 付ける。併せて技術者倫理、コミュニケーション等共通に必要とされ る知識・能力をこの範膞に加えることにより、共通知識・能力に対す る学習・教育目標の設定がより明確になると考えられる。

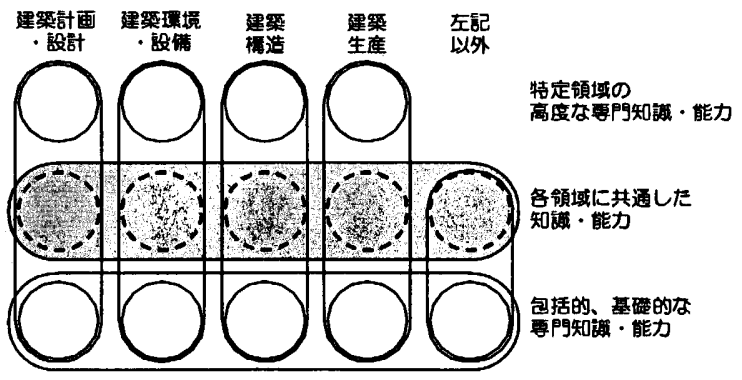

図3建築学およひ建築学関連分野要件の構成(案)

\section{6. まとめ}

設計・プロポーザル業務依頼内容及び対応方針の分析・整理により、 社会と市場の建築二ーズの变化、多様化、複雑化に対する建築づくり の上流・下流及び計画 - 設計 ·施工段階の業務の多様化、高度化、複 雑化々関与者の增加に伴うマネジメント業務の增大及びその重要性 が把暒できた。一方「JABEE」基隻及び認定プログラムの学習・教育 目標の分析から、マネジメントの側面が散りばめられているものの、 目標として体系立てて位置付けられていない事が認識できた。そこで マネジメント教育の明確化のためマネジメントの知識・能力を体系化 し、「JABEE」の分野別要件にマネジメントを含む共通知識・能力を 位置付けることを提案した。建築系教育において専門知識・能力に関 する教育が重要であることは言うまでもないが、マネジメントは実務 において建築系の専門知識・能力を最大限に発揮するための重要な基 本条件であり、またマネジメント業務が尃門職能としても位置付けら れてきている(PM、CM、FM 等)。従ってこれからの建築系教育に は専門知識・能力とマネジメントを含む共通知識・能力のバランスの とれた教育が重要と考える。

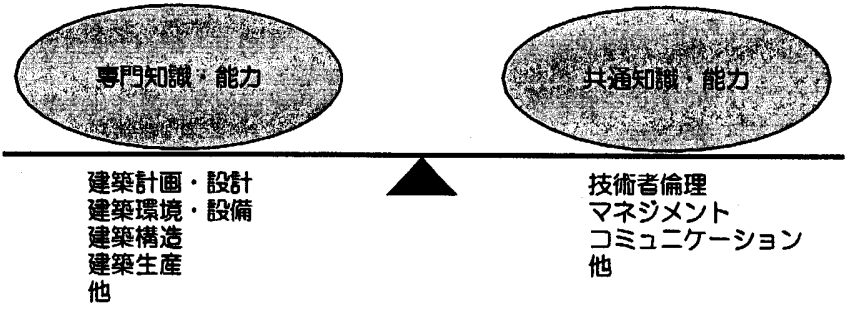

図4 専門知識·能力と共通知識·能力のバランスのとれた教育

社会・経済活動の器としての建築の質が厳しく問われる今日、建築 の質はデザインや技術の質だけでは評価されず、複雑多岐にわたる社 会や市場のニーズをいかに具体化し、期待を超える価値を提供できる かが重要な課題となり、競争が激化している。「マネジメント教育」 と別途研究を進めている「ニーズ及び業務の多様化への対応施策」が 建築系教育に位置付けられ、実業の動向にも対応した教育が展開され ることが、建築系教育の強化に役立つことを願っている。

\section{謝辞}

本稿の作成にあたり、国土交通省、日本技術者教育認定機構、日本 建築学会、建築業協会、建築分野「JABEE」認定取得大学および清水 建設、設計・プロポーザル統括 企画管理部他の貴重な资料を活用さ せて頂きました。資料の作成にあたり、牧謙二郎さん、馬場弘一郎さ んに協力して頂きました。また、原稿の作成にあたっては、黒岩 史 さんに多大な協力を頂きました。記して梁く感謝します。

\section{考文献}

1）建筑マネジメント教育の現状と課題（その1）大学教育に拈ける建筑マネジメン 卜の位管付け，金多隆 古阪秀三、日本建案学会大会学術請演梗概集, 2004.8

2）BCS 設計部門年次アンケート，建策業協会設計専門部会，2005.12

3）国土交通省総合政策局情報管理部建设調查統計鯟：平成 17 年度建設投資 見通し一概要とその要点一 国土交通省ホームページ，2005.6

4） 日本技術者教育認定機粠 : 学習・教育目標の設定と公開，2005 年度認定・ 蕃查用資料，pp. 37 40，2005.6

5） 日本建策学会 建築分野審查委員会 : 分野別要件一建勧学および建築学 関連分野一，建筑学および建筑学関連分野要件の知識・能力等の内容， 日本建筑学会ホームページ，建策教育認定重業（JABEE）2005 年度建筑 分野の蕃查

6) 北海道大学 工学部 億境社会工学科 建築都市コース 学習・教育目 標, カリキュラム, 北海道大学ホームページ，2005.12

7) 千集大学 工学部 デザインエ学科 建築系 学習・教育目標, カリキュ ラム、千葉大学ホームページ, 2005.12

8）広島大学 工学部 第四類（建設・摆境系）建勧プログラム プロダ ラムの到達目標, カリキュラム, 広島大学ホームページ, 2005.12

9) 熊本大学 工学部 建築学科 学習・教育目標, カリキュラム, 熊本大 学ホームページ, 2005.12

10）神奈川大学 工学部 建筑学科 学習・教育目標, カリキュラム, 神奈 川大学ホームページ, 2005.12

11）金沢工業大学 理境・建築学部 建築学科 学習・教育目標, カリキュ ラム，金沢工業大学ホームページ, 2005.12

12）大阪市立大学 生活科学部 住居境境学科 学習・教育目標, カリキュ ラム, 大阪市立大学ホームページ，2005.12

13）日本女子大学 家政学部 住居学科 学習・教育目標, カリキュラム， 日本女子大学ホームページ, 2005.12 